\title{
Employee's Job Performance: The Effect of Attitude toward Works, Organizational Commitment, and Job Satisfaction
}

\author{
Aries Susanty ${ }^{1 *}$, Rizqi Miradipta ${ }^{1}$
}

\begin{abstract}
Job satisfaction is a pleasurable or positive emotional state resulting from the appraisal of one's job and job experiences. The happier the individual, the higher is level of job satisfaction. It is assumed that positive attitude towards work and greater organizational commitment increases job satisfaction which in return enhances performance of the individual. Based on this phenomenon, this study is aimed to explain and empirically test the effect of attitude toward work, job satisfaction, and organizational commitment to the employee's job performance at PT. Intech Anugrah Indonesia (PT. Intech). Data used in this study was primary data which were collected through closed questionnaires with 1-5 Likert scale. A sample of this study was 200 managerial and non-managerial staff of PT. Intech. Research carried out by using Structural Equation Modeling (SEM) which was run by AMOS 20.0 program. The results of this study showed that attitude towards work have positive but not significant effect to job satisfaction and employee performance. Different with attitude towards work, the organization's commitment has positive and significant effect on job satisfaction and employee performance at PT. Intech. It means every improvement in organization's commitment has a positive effect toward job satisfaction and employee performance at PT. Intech.
\end{abstract}

Keywords: Attitude toward work, organizational commitment, job satisfaction, employee's job performance, structural equation modeling.

\section{Introduction}

Employee's job performance has been defined as work performance in terms of quantity and quality expected from each employee (Khan et al. [25]). With increase in competition, firms have recognized the importance of the employee's job performance to compete in this global market because as the performance of the employees increases, it will affect firm's performance and ultimately profitability of the firm. There are a number of factors that may be affecting the employees' job performance. Each employee may have a different effect from different things at the workplace (Zahargier and Balasundaram [60]). In the field of Industrial/Organizational Psychology, one of the most researched areas is the relationship between the employee's job performance and job satisfaction (Judge et al. [23]). Previous literature has emphasized more on the linear relationship between job satisfaction and job performance. According to Rashed [45] individuals would expect higher levels of job performance and it has always been associated with higher levels of job satisfaction, although they do not consistently correlate.

Robbins and Judge [47] define job satisfaction as the positive feeling about one's job resulting from an evaluation of its characteristic. It has been defined

\footnotetext{
$1^{*}$ Faculty of Engineering, Industrial Engineering Department, Universitas Diponegoro. Jl. Prof. Soedarto SH, Kampus Tembalangan, Semarang 50275, Indonesia.

Email: ariessusanty@yahoo.com, radipta@ymail.com.

${ }^{*}$ Corresponding author
}

differently by various scholars. Among the most accepted definition of job satisfaction is by Locke, who defined job satisfaction as a positive emotional feeling, a result of one's evaluation towards his job or his job experience by comparing between what he expects from his job and what he actually gets from it (Tat et al.[53]). Job satisfaction and dissatisfaction not only depends on the nature of the job, it also depends on the expectation what's the job supply to an employee (Al-Hussami [3]). Job satisfaction is a complex phenomenon with multi facets (Xie and Johns [58]); according to Linz [30], job satisfaction is influenced by attitudes toward work and organizational commitment. It is assumed that positive attitude towards work and greater organizational commitment increases job satisfaction which in return enhances performance of the individual ( $\mathrm{Linz}$ [30]).

According to Mowday, Porter, and Steers [40], attitude is termed as a hypothetical construct that represents an individual's like or dislike for any behavior. Bagozzi states that the term attitude is often used as an umbrella expression covering such concepts as preferences, feelings, emotions, beliefs, expectations, judgments', appraisals, values, principles, opinions, and intentions (Onzima [42). An attitude is actually defined as ". . . a summary evaluation of an object or thought" (Malhotra [32]). The object or phenomenon can be anything a person discriminates or holds in mind (Bohner and Wanke [6]) and may include people, products, and organizations. Attitudes may be positive, negative, or neutral (valence); may vary in intensity (extremity); 
can be more or less resistant to change; and may be believed with differing levels of confidence or conviction. Attitudes are composed of past and present experiences and are not observable as such, but are evidenced in behavior (Oskamp and Schultz [43]). Based on definition of attitude, it makes sense to conclude that how the employee behave in their job (satisfy or not) is depends on the result of a summary evaluation of the condition of their workplace.

Meyer and Allen [35] state that organizational commitment is a feeling of dedication to one's employing organization, willingness to work hard for that employer, and the intent to remain with that organization. In line with Meyer and Allen [35], Raju and Srivastava also state that organizational commitment is a factor that promotes the attachment of the individual to the organization. Employees are regarded as committed to an organization if they willingly continue their association with the organization and devote considerable effort to achieving organizational goals. Higher levels of effort exerted by employees with high levels of organizational commitment would lead to higher levels of performance and effectiveness of both the individual and the organizational level (Sharma and Bajpai [50]).

Related to the employee's job performance, as one of the electronic company in Indonesia, PT. Intech Anugrah Indonesia (PT. Intech) wants to know how much the effect given by following factors, i.e. attitude toward work, organizational commitment, and job satisfaction, toward their employee's performance. Curiosity of PT. Intech was based on the results of an assessment of their employee's performance which was demonstrating a number of employees who still have low performance. Employees who performed very well only $4.00 \%$, employees who performed good only $73.90 \%$, employees who performed enough $20.10 \%$, while the employees who performed poorly was $2.00 \%$. The factor which is having a great effect on the employee's performance of PT. Intech will be become the most important factor to improved seriously by the Human Resource Division.

Based on the condition that was faced by PT. Intech and the previous theory about the relationship between attitude toward work, organizational commitment, job satisfaction, and employee's performance, specifically this study aim to explain and empirically test the effect of attitude toward work, job satisfaction, and organizational commitment to the employee's job performance at PT. Intech.

\section{Methods}

\section{Study Literature and Hypothesis}

The literature shows a positive relationship between attitude towards work, organizational commitment, and job satisfaction. Literature also shows a positive relationship between job satisfaction and employee's job performance. Basically, this study refers to the conceptual model of previous research belong to Ahmad et al. [2]. Unlike the previous literature from Ahmad et al. [2], this study didn't see the relationship between job satisfaction and employee's job performance as two factors or variables that have a reciprocal relationship. In this study, job satisfaction only has a positive effect on an employee's job performance and not vice versa. It is because, this study only focused to see some factors or variables that affecting the employee's job performance.

\section{Attitude toward Works and Job Satisfaction}

Attitude towards works are the feelings that the workers have toward different aspects of the work environment. There are some element which influencing the attitude towards works, namely personality, person-environment fit, job characteristics, psychological contract, organizational justice, work relationship, and stress (Carpeter et al.[10]). Related to job satisfaction, Staw et al. refers to the functions of attitudes as the energizing and facilitative effects of positive affect (as one component of satisfaction) at the workplace (Riketta [46]). In line with Staw et al., Robbins [48] and some researchers indicate that job satisfaction is a general attitude an individual has toward the work. A high level of job satisfaction means a positive attitude toward work. If not, it is a discontent with work and indicates a negative attitude. Tella et al. [54] declares that job satisfaction is concerned with several attitudes including attitudes about the job characteristics, compensation and benefits, status, social security, advancement opportunities, technological challenges and respect. Based on the above, this study predicts:

Hypothesis 1: Attitudes toward work have a positive significant effect on job satisfaction.

\section{Attitude toward Works and Employee's Job Performance}

The attitude-performance problem has drawn extensive research from all fields of behavioral sciences over the past 70 years (Luu [31]). Arguments that support an attitude towards works cause performance usually refer to the functions of attitudes as guidelines and facilitators of behavior (e.g. Fishbein and Ajzen [17]; Eagly and Chaiken [15]; or Judge et al. [23]) or refer to the functions of attitudes as the motivational effects of the personal importance or identification with the job or organization (e.g., as a component or a consequence of the commitment; see Meyer et al. [36]). In the line with the previous opinion, Wei and Chu [55] performed a survey about the relationship between attitude toward work and job performance in the financial service industry and they found that work attitude has a positive effect on 
job performance. Better work attitude leads to better job performance. Based on the above, this study predicts:

Hypothesis 2: Attitudes towards work has a positive significant effect on an employyee's job performance

\section{Organizational Commitment and Job Satis- faction}

Many authors have defined the concept of organizational commitment in a number of ways (Demirer et al. [12]). Some experts view that commitment to the organization as the strength of involvement with an organization (e.g. Hall and Schneider [21] and Mowday et al. [40]). Others suggest that commitment is shown through congruence between personal and organizational goals and values (e.g. Buchanan [7]) or through an exchange of behavior for valuing rewards (e.g. Becker [5] and Meyer and Allen [35]. In another way, Mowday et al. [40] and Morrow [39] defined commitment as: (a) a belief in and acceptance of organizational goals and values; (b) a willingness to exert effort towards organizational goal accomplishment; and (c) a strong desire to maintain organizational membership

Tai et al. [52] observed that organizational commitment and job satisfaction are highly correlated. There are two opinions that related to the relationship between organizational commitment and job satisfaction. The first opinion, job satisfaction is a significant predictor of organizational commitment and the second opinion, organizational commitment is a significant predictor of job satisfaction. Dienhart and Gregoire [13] and LaLopa [26] were some of the researchers that supported the first opinion. Dienhart and Gregoire [13] revealed that many studies use different facets of satisfaction to predict employee attributes such as performance, organizational commitment, and service quality. In line with Dienhart and Gregoire, LaLopa [26] argued that job satisfaction is a significant predictor of organizational commitment. Different with Dienhart and Gregoire [13] and LaLopa [25], research which conducted by Markovits et al. [33] suggested that affective organizational commitment was found to be most influential with respect to levels of intrinsic and extrinsic job satisfaction. In line with research which conducted by Markovits et al. [33], research which conducted by Sharma and Bajpai [50] and Adeloka [1] also suggested that organizational commitment is being proven as the catalyst for enhancing the job satisfaction level of employees. So, Markovits et al. [33], Sharma and Bajpai [50], and Adeloka [1] were some of the researchers that supported the second opinion. This study tries to make some contribution to the literature that supported the second opinion (organizational commitment is a significant predictor of job satisfaction), so this study predicts:

Hypothesis 3: Organizational commitment has a positive significant effect on job satisfaction

\section{Organizational Commitment and Employee's Job Performance}

Beside impact on job satisfaction, many researchers have carried out various studies to examine the relationship between organizational commitment and employee's job performance. The findings of the previous studies have given varied results (Qaisar et al. [44]). Some have found a positive relationship between organizational commitment and performance (e.g. Bashaw and Grant [4], Kalleberg and Marden [24]; Suliman and Lles [51]; Meyer et al. [37]; and Khan et al. [25]), while others have examined very weak, negative or insignificant relationship between the two (e.g. Leong et al. [29], Wright [57], and Mathieu and Zajac [34]). Related to a positive relationship between organizational commitment and performance, Suliman and Lles [51] carried out a research on full time employees working with three companies of industrial sector in Jordan and explored that continuance organizational commitment has a positive association with employee job performance. Furthermore, Khan et al. [25] also conducted a research on employees working in oil and gas sector of Pakistan and examined positive and significant relationship between these two variables. Benkhoff, cited by Qaisar [44] believes that variation in results is due to the way commitment has been conceptualized. Based on the above, this study predicts:

Hypothesis 4: Organizational commitment has a positive significant effect on an employee's job performance

\section{Job Satisfaction and Employee's Job Perfor- mance}

Refers to a study conducted by Ahmad et al. [2], variable of job satisfaction is measured from the level of satisfaction of employees working in the company. The speculation that job satisfaction is related to performance dates back to the early days of the field of Industrial/Organizational Psychology and there were a complex relation between job satisfaction and performance. In 1930's some researchers were emphasized on their relationship and they were studied seriously at the notion that a happy worker is a productive worker. At that time it showed a weak and somehow a negative relationship between them, but Iaffaldano and Muchinsky [22] were proved that there was a correlation between job 
performance and job satisfaction and the value of the correlation was about 0.170 . A recent meta-analysis by Judge et al. [23] found a mean corrected correlation of 0.300 between satisfaction and performance. This relationship was much stronger than the corrected correlation of 0.170 found in an earlier meta-analysis by Iaffaldano and Muchinsky [22] and will likely stimulate a renewed interest in the study of the satisfaction-performance relationship. Beside Judge et al. [23], as cited by Dizgah et al. [14], Yi [59], Chen and Colin [11], Zimmerman and Todd [61], and Lee, et al.[28] were also some of the researcher that supported a positive relation between job satisfaction and job performance. Based on the above, this study predicts:

Hypothesis 5: Job satisfaction has a positive significant effect on an employee's job performance

\section{Conceptual Model}

Based on the five hypotheses above, the conceptual model of this study can be seen in Figure 1.

\section{Sample}

Subject of the present research is selected from managerial and non-managerial staff of PT. Intech. For sampling, simple random sampling was used. Total 200 subjects were randomly selected from managerial and non-managerial staff of PT. Intech and were given same questionnaire, in which, respondents indicated their opinion about their attitude toward work, and they feel about organizational commitment, their job satisfaction, and their performance.

\section{Instruments and Measures}

Fifty-one items were selected to test the relationship between attitude toward work, organizational com- mitment, job satisfaction, the employee's job performance. Out of these fifty-one items, twentyfive items were used to measure attitude toward work, fifteen items were used to measure organizational commitment, five items were used to measure job satisfaction, and seven items were used to measure employee's job performance.

Twenty-five items used to measure attitudes toward work can be described as follows: open to new ideas related to the work (x1); easy to socialize (x2); try to make achievements in accordance with the work (x3); always have a good trust to the colleagues (x4); always have a good mood when working (x5); always try to resolve the problems related to the work (x6); always confidence and respect himself (x7); believe the work will be successful (x8); feel that have performance and capability which is better than colleagues (x9); feel that have performance and capability which are never better than colleagues (x10); feel that have the same performance and capability with the colleagues (x11); always use all the skills to accomplish the work ( $\mathrm{x} 12)$; have an autonomy over the work (x13); have a willingness to receive feedback related to the work (x14); have a willingness to give a good contribution to the work environment (x15); always get the benefit from the job (x16); feel the presence of justice related to the company's policies and procedures related to the job (x17); feel the presence of justice related to the treatment of the supervisor (x18); feel the presence of justice related to the punishment related to job which is provided by the company (x19); feel the presence of justice related to award related to the job which is provided by the company (x20); always create a good relationship with the working group (x21); always create a good relationship with the supervisor (x22); never been in conflict with colleagues (x23); never been in the pressure to not make a mistake (24); and always feel safety in doing work (x25). All of these items were developed from explanation of Carperter et al. [10] about work attitudes that affect work behaviors.

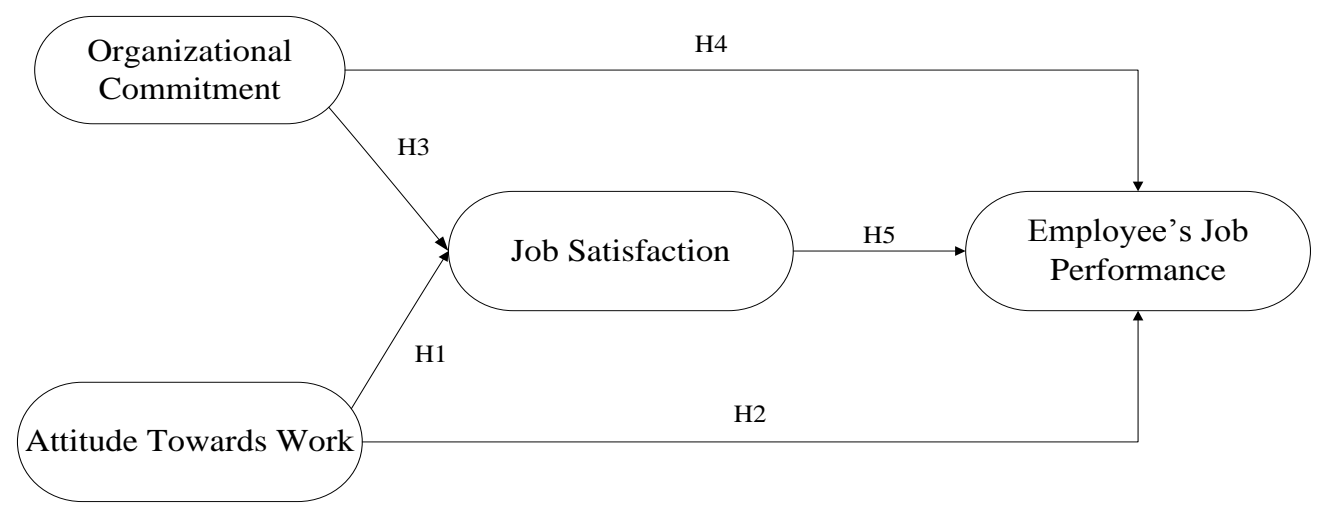

Figure 1. Conceptual model of this study 
Fifteen items were used to measure organizational commitment can be described as follows: willing to put in a great deal of effort beyond that normally expected in order to help this company be successful (x26); talk up this company to other friends as a great organization to work for (x27); feel loyalty to this company (x28); would accept almost any type of job assignment in order to keep working for this company (x29); find that my values and the company's value are very similar (x30); proud to tell others that being part of the company (31); this is the best of all possible companies for which to work (x32); never think to work for a different company although the type of job was similar (x33); the company really inspires the very best in me in the way of job performance (x34); the company take a big change in my present circumstances to cause me to stay this company (x35); extremely glad because have chosen this company to work for over others which was considered at the time joined the company (x36); so much to be gained by sticking with this company (x37); it very easy to agree with this company's policies on important matters relating to its employees (x38); really care about the fate of this organization (x39); and deciding to work for this organization was a best decision ( $\mathrm{x} 40)$. All of these items are based on Organizational Commitment Questionnaire (OCQ) developed by Mowday et al. [40]. The OCQ is characterized by three factors: (a) a strong belief in the acceptance of the organization's goals and values, (b) a willingness to exert considerable effort on behalf of the organization, and (c) a strong desire to maintain membership in the organization. The OCQ measures a combination of employee attitudes and behavioral intentions, reflective of the moral involvement of the employee with the organization

Five items were used to measure job satisfaction can be described as follows: feel satisfied with the content of the job (y1); feel satisfied with a physical condition which is related to the job (y2); feel satisfied with the opportunity to use the own ability (y3); feel satisfied with the rate of payment (y4); feel satisfied with future change of promotion (y5). All these items were a modification of the items measuring job satisfaction which was developed by Linz [30].

According to the research that conducted by Wiyadi [56], there were seven element to measure employee's job performance, i.e.: able to achieve target of production as set by the company (y6); able to produce high quality product accordance with the company's standard (y7); able to achieve target of production under time constraint (y8); able to show high productivity (y9); always come to the office in accordance with the time specified (y10); always follow the instruction that give by the supervisor (y11); and always careful in doing the job (y12).
In a measure of attitude towards work, organizational commitment, and job satisfaction, this study use 5-level Likert scale, whereas $1=$ strongly disagree, $2=$ disagree, $3=$ neither agree nor disagree, $4=$ agree, and $5=$ strongly agree. Although using a 5 Likert scale to measure employee's job performance, the meaning of each value in this scale was different from the previous measurement. In measure employee's job performance, $1=$ much worse than others, $2=$ worse than others, $3=$ similar to others, $4=$ better than others, $5=$ much better than others.

\section{Data Analysis Tools}

Research carried out by using Structural Equation Modeling (SEM) which was run by AMOS Program. The SEM is a second generation data analysis technique for estimating complex relationships among multiple constructs (Byrne [8]). The SEM and traditional statistic methods (e.g., regression, ANOVA, LOGIT) differ in important ways (Gefen et al. [18]) whereas traditional statistic methods can only test pairwise relationships between observed variables, the SEM can construct latent variables (abstract concepts that cannot be measured directly) and assess complex (e.g., hierarchical, recursive) causal paths among such variables. Therefore, the SEM technique has been increasingly used in social science, behavioral science and management science, for modeling complex and multivariate relationships.

\section{Results and Discussion}

\section{Characteristic of Respondent}

Characteristics of the respondents who completed a questionnaire in this study can be described as follows. Most respondents are male (63.000\%). Most respondents had ages between 21-30 years old (81.500 ); only $16.500 \%$ of respondent had ages between 31-40 years old and respondent had ages between $41-50$ years old only $2.000 \%$. As much as $72.500 \%$ of respondents have been joined with the company for $1-5$ years and $27.500 \%$ of respondents have been joined with the company for 6-10 years. Out of 200 respondents, $52.500 \%$ of respondent have managerial positions and $47.500 \%$ of respondent have non-managerial position.

\section{Basic SEM Assumptions}

There are some assumptions regarding SEM: Sample size: because SEM has the ability to model complex relationships between multivariate data, sample size is an important (but unfortunately underemphasized) issue. Two popular assumptions are that you need more than 200 observations, or at least 50 more than 8 times the number of variables 
in the model. A larger sample size is always desired for SEM (Ghozali [19]). Since this study use 200 participants were randomly selected from managerial and non-managerial staff of PT. Intech, this study has been fulfilled the assumptions regarding to sample size.

Normal distribution: this study also has been fulfilled the assumption about normal distribution of data which was used. The data used in this study have normal distributed as indicated by the value of CR Kurtosis and CR Skewness which were in the range between -2.580 until 2.580 (Ghozali [19]).

Outliers/data extreme: there were no outliers or data extreme in this study. Evaluation of outliers can be seen in the value of Mahalanobis distance which was smaller than the value of Chi-Square with a number $\mathrm{v}=$ number of indicators and $\mathrm{p}<0.001$.

\section{Confirmatory Factor Analysis}

Confirmatory Factor Analysis is used to test whether measures of a construct are consistent with a researcher's understanding of the nature of that construct (or factor). Four criteria in this study are used as summarized in Table 1. The first criterion is RMSEA (root mean square error of approximation). The RMSEA is acceptable or good when the value is less than 0.080 (Lee et al. [27]). The second criterion is GFI (goodness-of-fit index). The GFI is acceptable or good when the value greater than 0.900 . Although in this study, the value of GFI less than 0.900, it does not necessarily mean that the model has a poor fit because the GFI is scaled between 0 and 1; higher values indicating a better model fit (Miles and Shevlin [38]). The third criterion is RMR (root mean square residual). RMR is the square root of the mean of the squared discrepancies between the implied and observed covariance matrices. It is used to compare the fit of two different models with the same data. The RMR is acceptable or good when the value less than 0.050 (Fadlelmula [16]). The last criterion is CMIN/DF (chi-square fit index divided by degrees of freedom). The value of CMIN/DF in the range of 2 to 1 or 3 to 1 indicates acceptable fit between the hypothetical model and the sample data (Carmines and McIver [9]).

\section{Validity and Reliability Test}

As stated by Linn and Stewart, validity is the measure of the accuracy of an instrument used (questionnaire items) in a study (Said et al. [49]). To test the validity of questionnaire items, this study used standardized loading factor which is $>0.400$ (Hair et al. [20]). The result showed that: (i) two items from twenty five items which belongs to attitude toward work were not valid ( $\mathrm{x} 9$ and $\mathrm{x} 12$ ); (ii) all items which belong to organizational commitment and job satisfaction were valid; and (iii) only one item from seven items which belong to the employee's job performance was not valid (y10).

After removing some items from the questionnaire was not valid, the internal reliability of the items was verified by computing the Cronbach's Alpha (Nunnally [41]). Nunnally [41] suggested that a minimum Cronbach's Alpha of 0.600 sufficed for early stage of research. The Cronbach's Alpha estimated for attitude towards work scale was 0.994, organizational commitment scale was 0.899 , job satisfaction scale was 0.812 , and employee's job performance scale was 0.789. As the Cronbach's alpha in this study were all much higher than 0.600 , the constructs were therefore deemed to have adequate reliability.

\section{Hypothesis Test}

The results of testing the hypothesis are presented in the Table 2: (i) an attitude towards work had a significant positive effect on job satisfaction, but not significant ( $B=0.204, \mathrm{p}>0.05)$; so hypothesis 1 was not supported;(ii) an attitude toward work had a positive effect on the employee's job performance, but not significant $(B=0.068, \mathrm{p}>0.05)$, so hypothesis 2 was not supported; (iii) organizational commitment had a significant positive effect on job satisfaction (B $=0.649, \mathrm{p}<0.05$ ); so hypothesis 3 was supported; (iv) organizational commitment had a significant positive effect on the employee's job performance $(B$ $=0.262, \mathrm{p}<0.05)$, so hypothesis 4 was supported; and (v) job performance had a significant positive effect on the employee's job performance the employee's job performance $(B=0.724, p<0.05)$, so hypothesis 5 was supported.

In the meantime, this study failed to prove that attitude towards work had a positive significant effect on an employee's job performance and job satisfaction. Because attitude toward work were the feelings that's someone had toward different aspects of the work environment, no significant relationship between attitude towards work and employee's job performance and job satisfaction could be happening because the employee had little interest in their work. They wanted to increase their productivity not because they like their job but they wanted to get more money and this condition eventually could make them stressful and bitter. Since they little interest in the work, satisfaction has been hard for them to achieve. This was another form of motivation but was not sufficient to make the worker satisfy enough. Besides this issue, there are other issues that affect worker attitude and job satisfaction 
either in a negative or positive way. These issues include the management, employee, sociology, communication, culture, and work environment.

Although this study refers to the conceptual model of previous research belong to Ahmad et al. [2], there were some differences in the results obtained from this study compared with Ahmad et al. [2]. Based on the result of multiple regression, a study conducted by Ahmad et al. [2] could prove a significant effect of attitude toward work on job satisfaction, which was couldn't be proven in this study. In contrast, a study which conducted by Ahmad et al. [2] failed to prove a significant effect of organizational commitment to job satisfaction and a significant effect of job satisfaction on job performance, which was could be proven in this study. The similarity of this study with Ahmad et al. [2], both of studies couldn't prove the significant effect of attitude toward work on job performance. But, both studies could prove the existence of the significant effect of organizational commitment to job performance.

Related to the past research about organizational commitment, job satisfaction, and job performance, this research has been successful in supporting previous studies which have proven a significant effect of organizational commitment to job satisfaction and job satisfaction. More specifically, this result of the study supported the opinion that organizational commitment was the most influential factor or a significant predictor of job satisfaction and job performance and not vice versa. These results were in line with some of previous studies (e.g. Markovits et al. [33]; Sharma and Bajpai [50]; and Adeloka [1]) who found positive effects of organizational commitment to performance of personnel in different work settings. These results were also in line with some previous studies (e.g. Bashaw and Grant [4]; Kalleberg and Marden [24], Suliman and LIes [51]; and Meyer et al. [36]; and Khan et al. [25]) who found a positive relationship between organizational commitment and performance.

Related to the past research about job satisfaction and job performance this research has been successful in supporting previous studies which prove a significant effect of job satisfaction to job performance. This results were in line with some studies which conducted by Iaffaldano and Muchinsky [22], Yi [59], Chen and Colin [11], Zimmerman and Todd [61], Lee et al. [28], and Judge et al. [23]. This relationship was much stronger than the corrected correlation of 0.170 found by Iaffaldano and Muchinsky [22] or 0.300 found by Judge et al. [23]. This study found a mean corrected correlation of 0.724 between satisfaction and performance.

\section{Conclusion}

Since employee's job performance is one of the important factors for a business to compete in this global market, the present study aims to explain and empirically test the effect of attitude towards work, job satisfaction, and organizational commitment to the employee's job performance. Based on the result of hypothesis tests, this study indicates that attitude toward work did not have a significant effect on job satisfaction and job performance of the worker of PT. Intech. Then, based on the results of hypothesis tests, this study indicates that organizational commitment was a factor which has a significant effect on job satisfaction and job performance of the worker of PT. Intech and job satisfaction was a good predictor of job performance of the worker of PT. Intech. In this case, organizational commitment had a more significant effect to job satisfaction and employee's job performance at PT. Intech than attitude towards work.

Table 1. Result of confirmatory analysis

\begin{tabular}{lccccccc}
\hline \multirow{2}{*}{ Criteria } & \multirow{2}{*}{ Cut of value } & \multicolumn{2}{c}{ Exogenous model } & \multicolumn{2}{c}{ Endogenous model } & \multicolumn{2}{c}{ Full model } \\
\cline { 3 - 7 } & & Value & Result & Value & Result & Value & Result \\
\hline RMSEA & $\leq 0.08$ & 0.073 & Good & 0.036 & Good & 0.065 & Good \\
GFI & $\geq 0.90$ & 0.736 & Marginal & 0.954 & Good & 0.710 & Marginal \\
RMR & $\leq 0.05$ & 0.024 & Good & 0.011 & Good & 0.022 & Good \\
CMIN/DF & $1 \leq \mathrm{x} \leq 2 ;$ or & 2.069 & Good & 1.261 & Good & 1.839 & Good \\
& $1 \leq \mathrm{x} \leq 3$ & & & & & & \\
\hline
\end{tabular}

Table 2. Result of hypothesis test

\begin{tabular}{lcccc}
\hline \multicolumn{1}{c}{ Hypothesis } & $\begin{array}{c}\text { Standardized } \\
\text { regression weight }\end{array}$ & CR & P & Result \\
\hline An attitude towards work $\rightarrow$ job satisfaction (H1) & 0.132 & 1.390 & 0.165 & Not accepted \\
An attitude towards work $\rightarrow$ employee's job performance (H2) & 0.068 & 0.924 & 0.356 & Not accepted \\
Organizational commitment $\rightarrow$ job satisfaction (H3). & 0.649 & 5.629 & 0.000 & Accepted \\
Organizational commitment $\rightarrow$ employee's job performance (H4) & 0.262 & 2.524 & 0.012 & Accepted \\
Job satisfaction $\rightarrow$ employee's job performance (H5) & 0.724 & 5.929 & 0.000 & Accepted \\
\hline
\end{tabular}


The current study presented exhibit limitations that should be considered. The limitations are as follows: The sample size of the current study was 200 . Although this sample size met the minimum requirement but this sample study only came from one company. The researcher may use others company from a different sector as a sample to find out more about the relationship between attitude towards work, job satisfaction, and organizational commitment to the employee's job performance.

This study didn't include demographic variables like gender, income, age, department, and education of the respondents as a predictor variable which can give different effects on attitude towards work, job satisfaction, organizational commitment, and employee's job performance.

For the measurement of job performance, this study had not differentiate job performance measurements for different working groups (managers and nonmanagers) or different of geographic indicators. The measurement of job performance was also too general and subjective and just comparing the performance which was achieved by the employee against the performance of their colleagues. For next study, researcher may consider developing job performance measures that are more specific to accommodate different tasks of each job.

Furthermore, future researchers can include the other important variables like compensation, performance appraisal, promotion practices, etc. to determine their effect on employees' performance.

\section{Theoretical and Practical Implications}

This study revealed that organizational commitment was the important factor to get more attention from the management of PT. Intech because organizational commitment give a significant effect to increase employee's job performance and job satisfaction. Based on this finding, the executive of a company must try to recognize and implement such strategies which help to increase organizational commitment of the employees. Executives can instill organizational commitment in employees by stimulating employees and rewarding both quality performance and company loyalty, and creating a desirable corporate goal, values, and culture. Employees tend to have higher levels of commitment when there is a strong match between their personal values and goals and those of the organization. An employee who believes in, accepts, and internalizes the company goals is more likely to be committed to the organization than someone with conflicting values or goals.

From a theoretical perspective, our overall findings support the idea that organizational commitment, job satisfaction, and job performance are highly correlated. These findings support the theoretical rationale that organizational commitment is a significant predictor of job satisfaction and also a significant predictor of job performance. When an employee has positive feelings towards the organization, its values and objectives, it possible for him/her to be unsatisfied with the job he has in the organization. Besides that, the more committed the employees regard themselves, the more successful they become on the job. Otherwise, they will want to quit the organization and, when quitting isn't affordable, the quality of the service they provide will suffer. In this case, improvement reforms for human resources will have their effects of the increase in organizational commitment, job satisfaction, and job performance, and accordingly also on the performance of the company.

\section{Acknowledgment}

The authors would like to thank the Department of Human Resources of PT. Intech for the support in conducting the data collection in the companies. The authors would also like to thank to the Head of Department Industrial Engineering for the support in conducting this research that has made this research accomplished.

\section{References}

1. Adeloka, B., The Impact of Organizational Commitment on Job Satisfaction: A Study of Employees at Nigerian Universities, International Journal of Human Resource Studies, 2(2), 2012, pp. 1-17.

2. Ahmad, H., Ahmad, K., and Syah, I. A., Relationship between Job Satisfaction, Job Performance Attitude towards Work and Organizational Commitment, European Journal of Social Sciences, 18(2), 2010, pp. 257-267.

3. Al-Hussami, M., A Study of Nurses' Job Satisfaction: The relationship to Organizational Commitment, Perceived Organizational Support, Transactional Leadership, Transformational Leadership, and Level of Education, European Journal of Scientific Research, 22(2), 2008, pp. 286-295.

4. Bashaw, E. R., and Grant, S. E., Exploring the Distinctive Nature of Work commitments: Their Relationships with Personal Characteristics, Job Performance, and Propensity to Leave, Journal of Personal Selling and Sales Management, 14, 1994, pp. 41-56.

5. Becker, H. S., Notes on the Concept of Commitment, American Journal of Sociology, 66, 1960, pp. 32-40. 
6. Bohner, G., and Wanke, M., Attitudes and Attitude Change, Psychology Press, Brighton \& Sons, New York, NY, 2002.

7. Buchanan, B., Building Organizational Commitment: The Socialization of Managers in Work Organizations, Administrative Science Quarterly, 19(4), 1974, pp. 533-546.

8. Byrne, B. M., Structural Equation Modeling with AMOS: Basic Concepts, Applications, and Programming, Routledge, New York, 2010.

9. Carmines, E., and McIver, J., Analyzing Models with Unobserved Variables: Analysis of Covariance Structure, In G. Bohrnstedt and E. Borgatta (Eds.), Social Measurement: Current Issues, Sage, Beverly Hill, CA, 1981.

10. Carpenter, M., Talya, B., and Erdogan, B., Principles of Management, Flat World Knowledge, New York, 2009.

11. Chen, J., and Colin, S., The Impact of Locus of Control on Job Stress, Job Performance and Job Satisfaction in Taiwan, Leadership \& Organization Development Journal, 29(7), 2008, pp. 572-582.

12. Demirer, H., Güres, N., and Akgül, V., Organizational Commitment and Job Satisfaction: The Influence of Individual and Organizational Factors on Sales Person's Work Attitude in Travel Agencies, Journal of Social Sciences Institute, 7(14), 2010, pp. 41-62.

13. Dienhart, J. R., and Gregoire, M. B., Job Satisfaction, Job Involvement, Job Security, and Customer Focus of Quick-Service Restaurant Employees, Hospitality Research Journal, 16(2), 1993, pp. 29-44.

14. Dizgah, M. R., Chegini, M. G., and Bisokhan, R., Relationship between Job Satisfaction and Employee Job Performance in Guilan Public Sector, Journal of Basic and Applied Scientific Research, 2(2), 2012, pp.1735-1741.

15. Eagly, A. H., and Chaiken, S., The Psychology of Attitudes, Fort Worth, TX, Harcourt Brace Jovanovich, 1993.

16. Fadlelmula, F. K., Assessing Power of Structural Equation Modeling Studies: A Meta-Analysis, Education Research Journal, 1(3), 2011, pp. 3742.

17. Fishbein, M., and Ajzen, I., Attitudes towards Objects as Predictors of Single and Multiple Behavioral Criteria, Psychological Review, 81, 1974, pp. 29-74.

18. Gefen, D., Straub, D., and Boudreau, M. C., Structural Equation Modeling and Regression: Guidelines for Research Practice, Communications of the Association for Information Systems, 4(7), 2000, pp. 1-79.

19. Ghozali, I., Model Persamaan Struktural: Konsep dan Aplikasi dengan Program Amos 19.0, Badan Penerbit Universitas Diponegoro, Semarang, 2011.
20. Hair, J. F., Black, W. C., Babin, B. J., and Anderson, R. E., Multivariate Data Analysis, Pearson, Upper Saddle River Boston Columbus, San Francisco, New York, 2010.

21. Hall, D. T., and Schneider, B., Correlates of Organizational Identification as a Function of Career Pattern and Organizational Types, Administrative Science Quarterly, 17(3), 1972, pp. 340-350.

22. Iaffaldano, M. T., and Muchinsky, P. M., Job Satisfaction and Job Performance: A Meta Analysis, Psychological Bulletin, 97, 1985, pp. 251271.

23. Judge, T. A., Carl J. T., Joyce E. B., and Gregory K. P., The Job Satisfaction-Job Performance Relationship: A Qualitative and Quantitative Review, Psychological Bulletin, 2001, 127(3), pp 376-407.

24. Kalleberg, A. L., and Marden, P. V., Organizational Commitment and Job Performance in the US Labor Force, Research in the Sociology of Work, 5, 1995, pp. 235-57.

25. Khan, M. R., Ziauddin, Jam, F. A., and Ramay, M. I., The Impacts of Organizational Commitment on Employee Job Performance, European Journal of Social Sciences, 15(3), 2010, pp. 292298.

26. LaLopa, J. M., The Prediction of Organizational Commitment and Turnover in Resort Jobs, Journal of Hospitality and Tourism Research, 21(2), 1997, pp. 11-26.

27. Lee, F., Lee, T., and Wu, W., The Relationship between Human Resource Management Practices, Business Strategy and Firm Performance: Evidence from Steel Industry in Taiwan, The International Journal of Human Resource Management, 21(9), 2010, pp. 1351-1372.

28. Lee, Javalgi, J., and Olivia T., Goal Orientation and Organizational Commitment Individual Difference Predictors of Job Performance, 18(1), 2010, pp.129-150.

29. Leong, S. M., Randoll, D. N., and Cote, J. A., Exploring the Organizational CommitmentPerformance, Journal of Business Research, 29 (1), 1994, pp.57-63.

30. Linz, S. J., Job Satisfaction among Russian Workers, Working Paper, William Davidson Institute, University of Michigan, 2002.

31. Luu, H., The Relationship between Employee Attitudes and Organizational Performance: Evidence from Cooperative Retail Stores, Honors Thesis, Colgate University, 2011.

32. Malhotra, N. K., Attitude and Affect: New Frontiers of Research in the 21st Century, Journal of Business Research, 58(4), 2005, pp. 477-482.

33. Markovits Y., Davis A. J., and Dick R. V., Organizational Commitment Profiles and Job Satisfaction among Greek Private and Public 
Sector Employees, International Journal of Cross Cultural Management, 7(1), 2007, pp. 5670.

34. Mathieu, J. E., and Zajac, D. M., A Review and Meta-analysis of the Antecedents, Correlates, and Consequences of Organizational Commitment, Psychological Bulletin, 108, 1990, pp.17194.

35. Meyer, J. P., and Allen, N., Testing the "Side-bet Theory" of Organizational Commitment: Some Methodological Considerations, Journal of Applied Psychology, 69(3), 1984, pp. 372-378.

36. Meyer, J. P., Becker, T. E., and Vandenberghe, C., Employee Commitment and Motivation: A Conceptual Analysis and Integrative Model, Journal of Applied Psychology, 89,2004, pp.9911007.

37. Meyer, J. P., Stanley, D. J., Herscovitch, L., and Topolnytsky, L., Affective, Continuance, and Normative Commitment to the Organization: A Meta-analysis of Antecedents, Correlates, and Consequences, Journal of Vocational Behavior, 61, 2002, pp. 20-52.

38. Miles, J., and Shevlin, M., Effects of Sample Size, Model Specification and Factor Loadings on the GFI in Confirmatory Factor Analysis, Personality and Individual Differences, 25, 1998, pp. 85-90.

39. Morrow, P. C., Concept Redundancy in Organizational Research: The Case of Work Commitment, Academy of Management Review, 10(3), 1983, pp. 486-500.

40. Mowday, R., Porter, L., and Steers, R., The Measurement of Organizational Commitment, Journal of Vocational Behavior, 14(2), 1979, pp. 224-247.

41. Nunnally, J., Psychometric Theory, McGrawHill, New York, 1978.

42. Onzima, A. D., Behavior, Corporate Culture and Going Public: The Case of Uganda, Master Thesis, Department of Accounting and Finance, Makarene University, Uganda, 2011.

43. Oskamp, S., and Schultz, P. W., Attitudes and Opinion, Laurence Erlbaum Associates, Mahwah, NJ, 2005.

44. Qaisar, M. U., Rehman, M. S., and Suffyan M., Exploring Effects of Organizational Commitment on Employee Performance: Implications for Human Resource Strategy, Interdisciplinary Journal of Contemporary Research in Business, 3(11), 2011, pp. 248-255.

45. Rashed, A. A., The Effect of Personal Characteristics on Job Satisfaction: A Study among Male among Managers in the Kuwait Oil Industry, International Journal of Commerce \& Management, 11 (3), 2001, pp. 91-111.

46. Riketta, M., The Causal Relation between Job Attitudes and Performance: A Meta-Analysis of
Panel Studies, Journal of Applied Psychology, 93(2), 2009, pp. 472-481.

47. Robbins, S. P., and Judge, T.A., Organizational Behaviour, Prentice-Hall, New Jersey, 2007.

48. Robbins, S. P., Organizational Behaviour: Concept, Controversies, Applications, Prentice-Hall, New Jersey, 2001.

49. Said, H, Badru, B. B, and Shahid, M., Confirmatory Factor Analysis (Cfa) for Testing Validity and Reliability Instrument in the Study of Education, Australian Journal of Basic and Applied Sciences, 5(12), 2011, pp. 1098-1103.

50. Sharma, J. P., and Bajpai, N., Organizational Commitment and Its Impact on Job Satisfaction of Employees: A Comparative Study in Public and Private Sector in India, International Bulletin of Business Administration, 9, 2010, pp. 7-19.

51. Suliman, A., and LIes, P., Is Continuance Commitment Beneficial to Organizations? Commitment-performance Relationship: A New Look, Journal of Managerial Psychology, 15 (5), 2000, pp. 407-422.

52. Tai, T. W., Bame S. I., and Robinson C. D., Review of Nursing Turnover Research, 1977 1996, Social Science and Medicine, 47(12), 1998, pp.1905-1924.

53. Tat, H. H., Pei-Ni, T., and Rasli, A. Md., Job Satisfaction and Organizational Commitment in a Malaysian Public University's Library, International Journal of Management Sciences and Business Research, 1(6), 2012, pp. 1-7.

54. Tella, A., Ayeni, C. O., and Popoola, S. O., Work Motivation, Job Satisfaction and Organizational Commitment of Library Personnel in Academic and Research Libraries in OYO State Nigeria, Library Philosophy and Practice, Available: http://unllib.unl.edu/LPP/tella2.htm, 2007.

55. Wei, W. C., and Chu, S. H., Empirical Study on the Correlation among Personality Traits, Work Attitudes, Service Quality, Job Performances and Customers' Satisfaction - A Financial Holding Company in Taiwan, International Journal Lisrel, 1(2), 2008, pp. 1-24.

56. Wiyadi, S., Pengaruh Komitmen Organisasi, Motivasi Kerja, dan Budaya Kerja terhadap Kinerja Pegawai pada Direktorat Statistik Pertanian Badan Pusat Statistik, Final Report, Universitas Pembangunan Nasional Veteran, 2010.

57. Wright, T. A., Job Performance and Organizational Commitment, Perceptual and Motor Skills, 85(2), 1997, pp.447-50.

58. Xie, J. L., and Johns, G., Interactive Effects of Absence Culture Salience and Group Cohesiveness: A Multi-level and Cross-level Analysis of Work Absenteeism in the Chinese Context, Journal of Occupational and Organizational Psychology, 73, 2000, pp. 31- 52. 
59. Yi, H., The Relationship between Job Performance and Job Satisfaction, Organizational Commitment and Goal Orientation, Acta Psychological Sinica, 40(1), 2008, pp. 84-91.

60. Zahargier, M. S., and Balasundaram, N., Factors Affecting Employees' Performance in ReadyMade Garments (RMGs) Sector in Chittagong,
Bangladesh, Economic Sciences Series, LXIII(1), 2011, pp. 9-15.

61. Zimmerman, R., and Todd, D., The Impact of Job Performance on Employee Turnover Intentions and the Voluntary Turnover Process a Meta-Analysis and Path Model, Personnel Review, 38(2), 2009, pp.142-158. 